\title{
TECHNICAL EFFICIENCY IN TRANSPORT MANUFACTURING FIRMS: EVIDENCE FROM MALAYSIA
}

\author{
Mohd Fahmy-Abdullah*, Rahmah Ismail, Noorasiah Sulaiman, and \\ Basri Abdul Talib \\ Faculty of Economics and Management, Universiti Kebangsaan Malaysia, \\ 43600 UKM Bangi, Selangor, Malaysia \\ *Corresponding author: mohdfahmy@uthm.edu.my
}

Published online: 30 June 2017

To cite this article: Fahmy-Abdullah, M., Ismail, R., Sulaiman, N., and Abdul Talib, B. (2017). Technical efficiency in transport manufacturing firms: Evidence from Malaysia. Asian Academy of Management Journal, 22(1), 57-77. https://doi.org/ 10.21315/aamj2017.22.1.3

To link to this article: https://doi.org/10.21315/aamj2017.22.1.3

\begin{abstract}
This study aims to identify the level of technical efficiency and the determinants of technical inefficiency for transport manufacturing firms in Malaysia for 2010 using cross-sectional data of 130 firms acquired from the Department of Statistics (DOS). Based on the stochastic frontier analysis (SFA) approach, the results of the study reveal that the average level of technical efficiency is moderate. The estimated result identifies the important determinants of technical inefficiency which are due to employee wage rates as well as the cost of information and communication technology. The fundamental implications of this study are that transport manufacturing firms need to boost motivation among employees and strengthen the network of the production market via wage increment and communication cost.
\end{abstract}

Keywords: technical efficiency, technical inefficiency, firms, transportation, stochastic frontier analysis

(C) Asian Academy of Management and Penerbit Universiti Sains Malaysia, 2017. This work is licensed under the terms of the Creative Commons Attribution (CC BY) (http://creativecommons. org/licenses/by/4.0/). 


\section{INTRODUCTION}

Based on Debreu (1951) and Farrell (1957), technical efficiency refers to the one rejected by the reduction of the maximum proportion that still allows production to give a total output. In other words, the value of one indicates the level of technical efficiency and a score of less than one indicates the level of technical inefficiency (Porcelli, 2009).

Meanwhile, Kumbhakar and Lovell (2003) posited that technical efficiency defined as the capacity of a firm in producing a maximum output from a given set of inputs or producing the maximum output from the minimum quantity of inputs. The determinants of technical efficiency and their measurements are important in the theory of production. Technical efficiency is vital in determining the efficiency level of a firm or an industry as well as contributes to the economic growth of a country. Under the 10th Malaysia Plan, the issue of efficiencies has been addressed to create a more competitive economy in achieving developed nation status by 2020 .

In general, efficiency in transportation manufacturing firms contribute to the growth of productivity. Transportation manufacturing firm is one of the important sectors in the industry and considered as a production model for the movement of people and goods into shaping economic growth and job creation that supports public policies related to energy consumption. The firm also contributes to transport chain efficiency to reduce operational costs, improve delivery performance, increase customer satisfaction, and enable them to grow more competitive in terms of cost, quality, delivery, and flexibility (Perbadanan Produktiviti Malaysia, 2013/2014).

During the period between 2009 to 2013, the investment in the transport manufacturing industry was between RM700 million to RM5 billion in 2012 . Besides that, the total export earnings were RM5.3 billion, whereas the total import earnings were RM21.7 billion. Moreover, the export value for the automotive manufacturing subsector amounted to RM4.3 billion and the export of the passenger vehicles was RM700 million. In 2013, Malaysia recorded its total sales and vehicles' production at the third place after Thailand and Indonesia. Malaysia was also the third largest automotive market after Indonesia and Thailand in the segment of passenger cars in ASEAN (MITI, 2013). The sales increase is driven by the annual economic growth of $4 \%$ to $5 \%$, the introduction of the competitive pricing model, competitive price, and increased purchasing power of consumers. Meanwhile, the overall automotive sales increased from 536,905 units in 2009 to 652,120 units in 2013. 
For 2013, transport manufacturing firms have contributed $3.6 \%$ to the gross domestic product (GDP) and was an important component in the nation's growth (Perbadanan Produktiviti Malaysia, 2013/2014). In addition, the country has set a goal of making transport manufacturing industry as one of the National Key Economic Areas (NKEA) which enables the industry to not just be competitive locally but also at international level.

Eventhough the contribution of the transport manufacturing industry is increasing in Malaysia, the trade openness has made the industry to face more intense competition. Besides that, the industry is experiencing fluctuations which cause profit margins earned from production activities to become smaller (MITI, 2014). In this context, transport manufacturing firms must be more productive to achieve high productivity in ensuring towards the savings of production costs by increasing the efficiency of the firms.

Most studies of technical efficiency only focus on the level of technical efficiency. There is limited study on the determinants of technical efficiency. In fact, the most relevant on the level of technical efficiency analysis does not really use cross-sectional data at the firm or micro level. As a result, the level of technical efficiency obtained is not significant. Battese and Coelli (1995) pointed out that by considering the factors of technical inefficiencies, data at firm level can play an important role to obtain an accurate value of technical efficiency. In addition, this micro data is also more efficient compared to the time-series data as the researcher has the advantage of solving some of the problems associated with the estimates and the bias aggregation to aggregated industry data (Md Isa, 2005).

New empirical findings can be generated when using data at the firm level taking into account, factors that may decrease the efficiency of improvement efforts. Tingley, Pascoe, and Coglan (2005) support this by stating that estimations using firms' data as well as individuals are considered a more advanced analysis of the factors affecting the level of budgeting which can be studied. Thus, studies that use data at the firm level by taking into account the factors of technical incompetence will bring more significant and appropriate results.

Based on the research problem, the main objective of the study is to examine the level of technical efficiency of transport manufacturing firms in Malaysia considering all six subsectors. Besides that, this study analyses the determinants of technical inefficiency in transport manufacturing firms. 


\section{LITERATURE REVIEW}

This study involved a cross-sectional data at the firm level or micro level. This type of data is becoming increasingly popular among researchers. More efficient budgeting can be generated through microdata relative to the time series data in aggregate form. In addition, the problem of heterogeneity and bias which occurs to aggregate macro data can be overcome. This type of data also highlight each firm's distinctiveness, such as capital intensity and use of technology, or is expected to be heterogeneous. At the same time, the data at firm level can also identify the determinants of technical efficiency.

However, there are limited studies in Malaysia, particularly on firms, that use data to measure the level of technical efficiency. Several empirical studies in other countries (Pitt \& Lee, 1981; Lieberman \& Dhawan 2005; Radam, Abu, \& Abdullah, 2008) used firms' data by using the firms' data on budget, and then determine the efficiency of variables of specific firms (including management experience, characteristics ownership, etc.) in an effort to identify some of the factors contributing to the efficiency differences between firms within the industry.

There are other studies that investigate the determinants of technical efficiency by positing that the capital-labour ratio can reduce engineering inefficiencies, thus increase the efficiency of the technique (Stevens \& Kneller, 2003; Minh, Long, \& Thang, 2007). Bertrand (2013) stated that a composition in the use of capital has a positive impact on efficiency when production levels increased in the event of high usage of machines in the production process. While Barrett and O'Connell (2001) found that the effects of exercise (either in general or specific) such as workplace training (on-the-job training) has a direct relation to the increase in productivity. This is supported by Almeida and Carneiro (2009), and Essmui, Madeline, Faridah, and Shamshubarida (2013).

Petrakis and Stamatakis (2002) posited that the benefits of higher education and secondary education is much higher in developing countries than in developed countries. Most of the other studies also showed increased levels of employee education can increase firms' production (Andersson, Holmlund, \& Lindh, 2002). The number of years of schooling or education could be one of the important roles in identifying the performance of the firm, including output, profits, and productivity (Idiong, 2007; Ajibefun, 2008; Murthy, Sudha, Hedge, \& Dakshinamoorthy, 2009).

Batra and Tan (2003) found that the level of technical efficiency increases with the enlargement of firm's size. However, there are also some small firms that operate more efficiently than the larger size. Despite an improvement in the level 
of technical efficiency with the firm size, this situation has undermined the policy of small and medium industries (Mini and Rodriguez, 2000). Other studies such as by Sinani, Jones, and Mygind (2008); Amornkitvikai, Harvie, and Charoenrat (2014); and Charoenrat, Harvie, and Amornkitvikai (2013) showed that the size of the firm can affect the level of technical efficiency of firms. Badunenko, Fritsch, and Stephan (2008) contradicted with others and found that the firm size does not affect the efficiency of such techniques.

In addition, a study in China by Huang, Hallam, Orazem, and Paterno (1998) showed that the efficiency and productivity changes are more influenced by wage rates compared with the human capital factor. However, Mazumder and Adhikary (2010) found that spending on the welfare of employees, including increasing the rate of wages, is not an important factor in determining the level of technical inefficiency in a firm.

In addition, some previous studies show that ICT cost in developed countries is positively significant, but not in developing countries. Meng and Li (2002) stated that there is a big gap between China and developed countries in the development of the ICT industry. Chowdhury (2006) found that excessive ICT investment and incompatibility between human capital and technology will result in negative impact on efficiency and productivity. There is a possibility that the ICT capital investment needs some time to have an impact on productivity. Although, theoretically, the impact of ICT is positive over time, but some studies have found the results obtained are varied (Hempell, 2005; Giuri, Torrisi, \& Zinovyeva, 2008).

In Malaysia, the efficiency of transport engineering manufacturing firms received less attention from researchers compared to other industries. An example of other countries that studied the transportation manufacturing industry includes Alvarez and Crespi (2003), and Chu and Kalirajan (2011) in Chile and Vietnam, which posited that the efficiency of transport manufacturing sector has a significant contribution to the manufacturing industry. This is similar to a study conducted by Karunaratne (2012) in Australia. In the US, Petrin, White, and Reiter (2011) found that growth will slow down in manufacturing sector despite the finding that the level of technical efficiency of transport as a whole provides a significant contribution to economic growth in the country.

Amdun (2007), Rosli and Kari (2008), and Khalifah (2013) only compared the performance of manufacturing sector focusing on local transportation firms with foreign firms. The achievement of technical efficiency of foreign firms is much higher. The studies also found that the average technical efficiency among the ownership groups did not indicate significant differences. Factors such as skilled 
labour, skills training, subsector size, and high quality of the workforce are driven towards improving technical efficiency.

However, the study did not use firms' data which takes into account more precise and significant factors that can lead to inefficiencies techniques. This contradicts with studies that concentrate on transport manufacturing firm which take into account the factors of inefficiency and the use of firms' data.

\section{THEORETICAL FRAMEWORK AND MODEL SPECIFICATION}

\section{Stochastic Frontier Analysis}

To yield the technical efficiency value of a firm, stochastic frontier analysis (SFA) was used by Aigner, Lovell, and Schmidt (1977), and Meeusen and van den Broeck (1977), followed by Battese and Coelli (1995). Efficiency at the frontier level can be measured by estimating manufacturing SFA model derived from sample performance or the top-performing firm which can be adopted to mirror the technological advancement being used by the whole sample or industry. Meanwhile, samples that performed below the frontier are considered inefficient, hence there is a need to increase productivity and advancement in technology or managerial and quality such as educational level (Jaafar, Mustapha, \& Talib, 2004). Cullinane, Wang, Song, and Ji (2006) insist that the SFA approach can analyse structure, examine determinants and production performance.

SFA is also widely used in measuring technical efficiency, allocative efficiency, and economic efficiency for the transport industry. Oum and Yu (1998), Inglada, Coto-Millan, and Rodriguez-Alvarez (1999), Sanchez and Villarroya (2000), and Vitaliano (2002) used this technique to estimate technical efficiency of this sector. Following Battese and Coelli (1995), the stochastic production function can be written as follows:

$$
\mathrm{Y}_{i}=\mathrm{X}_{i} \beta+\left(\mathrm{v}_{i}-\mathrm{u}_{i}\right)
$$

In equation (1), $i(i=1,2, \ldots, \mathrm{n})$ represents the number of input respectively. The output variable, $\mathrm{Y}_{i}$, represents the output of the $i$-th firm; the explanatory variable, $\mathrm{X}_{i}$, represents a vector of $\mathrm{K}$ inputs; $\beta$ represents a vector of $\mathrm{K}$ unknown parameters; and $\mathrm{v}_{i}$ is a random variable which is assumed to be $N\left(\mu, \sigma_{\mathrm{v}}{ }^{2}\right)$ as well as independent from $\mathrm{u}_{i}$, the specific error term which is attributed as the inefficiency effect in the model. Non-negative truncation of the distribution of $\mathrm{u}_{i}$ is assumed to be $N\left(\mu, \sigma_{\mathrm{v}}{ }^{2}\right)$. The variance parameter of the model can be parameterised as $\sigma^{2}=\sigma_{\mathrm{v}}{ }^{2}+\sigma_{\mathrm{u}}{ }^{2}$ and 
$\gamma=\sigma_{\mathrm{u}}^{2} /\left(\sigma_{\mathrm{v}}{ }^{2}+\sigma_{\mathrm{u}}^{2}\right)$ where $\sigma^{2}$ is the variance of output (Battese \& Corra, 1977). Here, $\gamma$ lies between 0 and 1. A value of $\gamma$ from zero indicates the deviations from the frontier is entirely due to noise and while the value is one, it indicates that all the deviations are due to technical inefficiency (Coelli, Rao, O'Donnell, \& Battese, 2005; Arunsawadiwong, 2007; Tran, Grafton, \& Kompas, 2008). The model incorporates a simplified specification inefficiencies following Battese and Coelli (1992) as follows:

$$
\mathrm{u}_{i}=\exp [-\eta(\mathrm{t}-\mathrm{T})] \mathrm{u}_{i}
$$

Here, $\mathrm{u}_{i}$ is the technical inefficiency effect in the model, the unknown parameter $\eta$ needs estimation that determines whether inefficiencies are time varying or not. Positive, zero and negative values of $\eta$ correspond to declining, constant, and increasing technical inefficiency overtime when $\eta$ is negative.

Following Battese and Coelli (1995), the inefficiency distribution parameter, which can be estimated from the maximum likelihood estimation (MLE) model, can be written as:

$$
\mathrm{u}_{i}=\sigma_{i} \mathrm{~W}_{i}+\mathrm{z}_{i}
$$

Where, $\mathrm{u}_{i}$ is technical inefficiency, $\mathrm{W}$ represents the controllable variables that can affect technical inefficiency and $\mathrm{z}$ represents the uncontrollable variable. According to Coelli et al. (2005), the technical efficiency of the $i$-th firm is as follows:

$$
\mathrm{TE}_{i}=E\left[\exp \left(-u_{i}\right)\right]
$$

The range of TE is 0 to 1 . TE $=1$ implies that the firm is producing on its production frontier and is said to be technically efficient. Hence, $(1-\mathrm{TE})$ represents the gap between actual production and optimal attainable production that can be achieved by moving the firm towards the frontier through readjusting inputs (Chavas \& Aliber, 1993).

\section{Model Specification}

The two model specifications normally adopted in stochastic frontier studies are presented in Cobb-Douglas function (5) and translog function (5) as follows:

$$
\ln Y_{i}=\beta_{0}+\beta_{1} \ln \mathrm{K}_{i}+\beta_{2} \ln \mathrm{L}_{i}+\left(\mathrm{v}_{i}-\mathrm{u}_{i}\right)
$$




$$
\begin{aligned}
\ln Y_{i}= & \beta_{0}+\beta_{1} \ln \mathrm{K}_{i}+\beta_{2} \ln \mathrm{L}_{i}+\frac{1}{2} \beta_{3}\left(\ln \mathrm{K}_{i}\right)^{2}+\frac{1}{2} \beta_{4}\left(\operatorname{lnL}_{i}\right)^{2} \\
& +\beta_{5}\left(\operatorname{lnK}_{i} \times \ln \mathrm{L}_{i}\right)+\left(\mathrm{v}_{i}-\mathrm{u}_{i}\right)
\end{aligned}
$$

where $Y_{i}$ is the $\log$ for the amount of nominal output of the $i$-th firm, $\mathrm{K}$ is the log for the amount of nominal asset of the $i$-th firm. Whereas, $\mathrm{L}$ is the $\log$ for the amount of labour for the $i$-th firm and $\mathrm{v}_{i}$ is the random variable or random effect, identical and normally distributed (independent and identically distributed, IID), normally distributed with $\left[N\left(0, \sigma_{\mathrm{v}}{ }^{2}\right)\right]$. Meanwhile, $\mathrm{u}_{i}$ is the non-negative random variable that can be assumed to explain inefficiency in production which is normally assumed to be IID as truncated at zero for distribution $\left[N\left(\mathrm{~m}_{i}, \sigma_{\mathrm{u}}{ }^{2}\right)\right]$.

The variables incorporated within the technical inefficiency component of the SFA model are as follows:

$$
\begin{aligned}
\mathrm{u}_{i}= & \delta_{0}+\delta_{1} \ln \mathrm{K} / \mathrm{L}_{i}+\delta_{2} \operatorname{lnTRE} \mathrm{TR}_{i}+\delta_{3} \operatorname{lnSEC} / \mathrm{L}_{i}+\delta_{4} \operatorname{lnTIER} / \mathrm{L}_{i} \\
& +\delta_{5} \ln \mathrm{W} / \mathrm{L}_{i}+\delta_{6} \ln \mathrm{ICT}_{i}+\delta_{7} \operatorname{lnDFSME} \ln _{i}
\end{aligned}
$$

where $\mathrm{u}_{i}$ is technical inefficiency, $\mathrm{K} / \mathrm{L}_{i}$ represents the total capital ratio divided by the number of employees for the $i$-th firm, TRE represents the amount of employee training expenses for the $i$-th firm, $\mathrm{SEC} / \mathrm{L}_{i}$ represents the ratio of employees trained at diploma level and STPM or equivalent for the $i$-th firm, TIER/L $\mathrm{L}_{i}$ represents the ratio of employees trained at a higher level including advanced degree or equivalent for the $i$-th firm, W/L $\mathrm{L}_{i}$ is the wage rate for the $i$-th firm, $\mathrm{ICT}_{i}$ is the communication cost for the $i$-th firm, and DFSME is the dummy for the $i$-th firm with small firms size represent 1 and others are considered 0 .

Hypothesis-testing based on likelihood ratio will be conducted to choose the type of function and to determine the existence of inefficiency. The first test is choosing the type of function either Cobb-Douglas production model or translog through maximum likelihood estimation. The second test is to find out whether the effects of inefficiency exist. Various hypothesis-testing of the parameters in the frontier production function can be performed using the likelihood ratio (LR) test statistic, $\lambda$, given by:

$$
\lambda=-2\left\{\ln \left[\lambda\left(H_{0}\right) / \lambda\left(H_{1}\right)\right]\right\}=-2\left\{\ln \left[\lambda\left(H_{0}\right)\right]-\ln \left[\lambda\left(H_{1}\right)\right]\right\}
$$

where $\lambda\left(H_{0}\right)$ and $\lambda\left(H_{1}\right)$ denote the value of the log likelihood function under the null and alternative hypothesis respectively (Coelli, Rao, \& Battese, 1998). The necessary tests with respect to other estimated parameters of the variables will be performed as in the case of the normal analysis. FRONTIER 4.1 programme (Coelli, 1996) was employed to analyse MLE in order to get the technical efficiency (TE) value. 


\section{Source of Data and Variable Identification}

The study used data collected at the firm level of the manufacturing industries which is controlled by the Department of Statistics (DOS). This data includes data in 2010 and in which the firms can be categorised into six subsectors on the 3-digit level by the Malaysian Standard Industrial Classification (MSIC 2008).

The data consists of manufacturing of motor vehicles, passenger cars, and commercial vehicles; manufacturing of template (coachwork) for motor vehicles and manufacturing of trailers and semi-trailers; manufacturing of parts and accessories for motor vehicles; ship and boat building, shipbuilding and floating structures and construction of leisure boats and sports; construction of air and spacecraft and related machinery; transportation equipment manufacturing activities not elsewhere classified; and manufacturing of motorcycles and bicycles and invalid carriages.

The study used data at the firm level so that a more significant and accurate result can be obtained. TE estimation using data as an individual firm is better because further analysis of the determinants affecting the level of TE can be studied. In addition, the microdata is also more effective than the time-series data as the researcher has the advantage to solve some of the problems associated with the estimation and aggregation on the bias of aggregate industry data (Md Isa, 2005).

\section{RESULTS AND DISCUSSION}

\section{Hypothesis Test}

The MLE result for the parameter in the SFA model through the Cobb-Douglas production model and translog as defined by equations (5) and (6) yielded using the FRONTIER 4.1 programme and the result is presented in Table 1.

Table 1

Generalised log-likelihood tests of hypotheses

\begin{tabular}{lcl}
\hline & $H_{0}: \beta_{\mathrm{ij}}=0$ & $H_{0}: \gamma=0$ \\
\hline LR statistic (Chi-Square) & $15.324^{* *}$ & $50.001^{* *}$ \\
Critical value & 7.815 & 16.274 \\
Decision & Reject $\mathrm{H}_{0}$ & Reject $\mathrm{H}_{0}$ \\
\hline
\end{tabular}

** significant at 5\% levels 
The first test is to choose the type of production function, whereby the null hypothesis represents Cobb-Douglas production model. LR statistical value to test null hypothesis, $\mathrm{H}_{0}:{ }_{i j}=0$, being counted as $L R=-2=15.324$. This value was compared to the critical value for distribution (at the highest 5\% level), 7.815. Based on the comparison, Cobb-Douglas production model was rejected whereas translog production model was selected as it was deemed suitable to represent the data under the study.

The second hypothesis-testing is to determine that there is no effect of technical inefficiency $\left(\mathrm{H}_{0}: \gamma=0\right)$ in the transport manufacturing firms. The result of the hypothesis-testing shows statistical value at 50.001 was greater than the critical value at 5\% significance level; 16.274 which indicates the existence of technical inefficiency that affects transport manufacturing firms in Malaysia.

This test supports a certainty of inefficient firms' existence which enables further testing to be done. The testing performed used data obtained from the firms to identify the factors affecting engineering firms inefficiency. This analysis is in contrast with most previous studies, such as Khalifah (2013), Ismail and Jajri (2008), Rosli and Kari (2008), and Amdun (2007) which have ignored the determinants of technical inefficiency.

\section{Descriptive Statistics}

This study was conducted on 130 transport manufacturing firms in Malaysia in 2010. Table 2 displays descriptive statistics of the variables used for SFA estimation. The table exhibits the overall average amount of output produced by the transport manufacturing firms which was RM310 million with a minimum of RM7 million to a maximum of RM8 billion. Capital is a major expense for transport manufacturing firms with the average spending of RM64 million between RM70,000 to RM2 billion. In addition, the average number of employees employed was 510 people ranging from 16 to 8,198 people. The study also found that the ratio between capital and labour in the transport manufacturing firms ranged from RM124 to RM165,000 with an average of RM120,000. Furthermore, the transport manufacturing firms had spent an average of RM301 million, with expenditures ranging from RM0 to RM11 million, for the cost of employee training. Besides that, the average ratio of employees with the highest qualification, including advanced degree or equivalent, was 0.083 ranging from 0.004 to 1.000 . As for the ratio of employees having a diploma and Malaysian Higher School Certificate or equivalent, it shows an average range of 0.164 , ranging from 0.000 to 0.868 . Furthermore, the firms' employees average wage in the year was RM27,000 ranging between RM7,000 to RM91,000. The firms had also spent an average of 
RM400,000 for ICT with minimum spending of RM2,000 and maximum spending of RM9 million. Meanwhile, SME dummy showed that $60 \%$ of the firms involved in this study were small-sized and medium-sized firms. Standard deviation showed that the variance fell over the entire sample. The result also showed that there was too much dispersion in the transport manufacturing firms.

Table 2

Descriptive statistics of the variables

\begin{tabular}{lcrrrr}
\hline Variable & \multicolumn{2}{c}{ Mean } & Minimum & Maximum & Standard deviation \\
\hline $\mathrm{Y}$ & $(\mathrm{RM})$ & 310,523 & 7,222 & $8,056,806$ & 1068269.655 \\
$\mathrm{~K}$ & $(\mathrm{RM})$ & 64,984 & 70 & $2,075,002$ & 218390.620 \\
$\mathrm{~L}$ & & 510 & 16 & 8,198 & 994.617 \\
$\mathrm{~K} / \mathrm{L}$ & $(\mathrm{RM})$ & 120.983 & 1.241 & 1648.844 & 200.300 \\
$\mathrm{TRE}$ & $(\mathrm{RM})$ & 301 & 0 & 11,403 & 1201.330 \\
TIER & Ratio & 0.083 & 0.004 & 1.000 & 0.104 \\
SEC & Ratio & 0.164 & 0.000 & 0.868 & 0.148 \\
$\mathrm{~W}$ & $(\mathrm{RM})$ & 27.042 & 7.800 & 91.660 & 12.515 \\
ICT & (RM) & 400 & 2 & 9,013 & 1053.222 \\
DFSME & Number & 0.400 & 0 & 1 & 0.492 \\
\hline
\end{tabular}

Notes: $\mathrm{Y}=$ output; $\mathrm{K}=$ capital; $\mathrm{L}=$ labour; $\mathrm{K} / \mathrm{L}=$ ratio of capital labour; $\mathrm{TRE}=$ employee training expenses; $\mathrm{SEC} / \mathrm{L}=$ ratio of employees trained at diploma level and Malaysian Higher School Certificate or equivalent; $\mathrm{TIER} / \mathrm{L}=$ ratio of employees trained at a higher level including advanced degree or equivalent; $\mathrm{W} / \mathrm{L}=$ wage rate; ICT $=$ communication cost DFSME = dummy for small medium firms size

\section{Technical Efficiency Analysis}

Table 3 displays the frequency and the index distribution of technical efficiency in the transport manufacturing subsector in Malaysia in 2010. This finding describes the contribution of technical efficiency of a firm in transport manufacturing subsector. The findings revealed that the subsector 3 - manufacturing of parts and accessories for motor vehicles - contributed to the most number of firms that participated in this study, i.e. 63 firms or $48.47 \%$. Subsector 4 - ship and boat building, shipbuilding and floating structures, and construction of leisure boats and sports - consists of 26 firms or $20.02 \%$.

If scrutinised closely, the frequency and index distribution of technical efficiency between 0.81 to 0.90 were the highest range of the overall subsectors, i.e. $23.08 \%$, followed by index distribution of technical efficiency between 0.71 to 0.80 which was $16.93 \%$. These results were driven by higher demand due to the rapid economic growth of between $4 \%$ to $5 \%$ per annum and increase in purchasing power. Thus, 
firms have increased the level of efficiency through the use of modern technology and improving the skills of employees (MITI, 2013).

Table 3

Frequency and index distribution of technical efficiency based on subsectors of transport manufacturing firms in Malaysia

\begin{tabular}{lcccccc}
\hline \multicolumn{7}{c}{ Technical Efficiency Range (subsector) } \\
\hline Per cent & 1 & 2 & 3 & 4 & 5 & 6 \\
\hline$\leq 0.20$ & 0.77 & 0.77 & 3.08 & 4.62 & 0.00 & 0.00 \\
$0.21-0.30$ & 0.00 & 0.77 & 2.31 & 2.31 & 1.54 & 1.54 \\
$0.31-0.40$ & 0.00 & 0.00 & 3.08 & 1.54 & 1.54 & 0.77 \\
$0.41-0.50$ & 0.00 & 0.00 & 5.38 & 3.08 & 0.00 & 0.77 \\
$0.51-0.60$ & 0.77 & 0.77 & 6.15 & 0.00 & 0.77 & 0.00 \\
$0.61-0.70$ & 1.54 & 0.77 & 4.62 & 2.31 & 0.00 & 1.54 \\
$0.71-0.80$ & 0.00 & 0.77 & 13.08 & 1.54 & 0.00 & 1.54 \\
$0.81-0.90$ & 3.85 & 0.00 & 9.23 & 2.31 & 0.77 & 6.92 \\
$0.91-100$ & 0.77 & 0.00 & 1.54 & 2.31 & 0.00 & 2.31 \\
Mean & 7.70 & 3.85 & 48.47 & 20.02 & 4.62 & 15.39 \\
\hline
\end{tabular}

Notes: 1 = manufacturing of motor vehicles, manufacturing of passenger cars and commercial vehicles

$2=$ manufacturing of template (coachwork) for motor vehicles and manufacturing of trailers and semi-trailers

$3=$ manufacturing of parts and accessories for motor vehicles

$4=$ ship and boat building, shipbuilding and floating structures, and construction of leisure boats and sports

$5=$ construction of air and spacecraft and related machinery

$6=$ transportation equipment manufacturing activities not elsewhere classified, manufacturing of motorcycles and bicycles and invalid carriages

\section{Determinants of Technical Inefficiency}

Table 4 illustrates the results of parameter estimator of stochastic frontier production model 2010 using FRONTIER 4.1, which was developed by Coelli (1996). The results of the analysis show that the most input parameter estimator in transport manufacturing industry is significant at 1\% significant level. Each input can be explained by the significant output. When there was an increase of $1 \%$ in the capital, the total output increased by $0.700 \%$. Similarly, when there was an increase of $1 \%$ in the amount of labour, the total output increased by $0.116 \%$.

The gamma value based on the analysis conducted is 0.322 . The significant technical inefficiencies had a significant impact on the level and production change of transport manufacturing firms in this study. Apart from that, parameter sigma squared is also significant in implying that firms that operated in an inefficient manner, and budgeting of stochastic frontier production model is better than the average production model in analysing industrial production processes. 
Table 4

Parameter estimation of stochastic frontier production model

\begin{tabular}{lcc}
\hline Variable & Coefficient & t-ratio \\
\hline Constants $\left(\mathrm{B}_{0}\right)$ & 0.892 & $8.979 * * *$ \\
LnCapital $\left(\mathrm{B}_{1}\right)$ & -0.048 & -0.160 \\
LnLabour $\left(\mathrm{B}_{2}\right)$ & -0.284 & -0.613 \\
$0.5(\mathrm{LnK} \mathrm{LnK})\left(\mathrm{B}_{3}\right)$ & 0.215 & 3.429 \\
$0.5\left(\mathrm{LnL}{ }^{*} \mathrm{LnL}\right)\left(\mathrm{B}_{4}\right)$ & 0.488 & 3.473 \\
LnK*LnL $\left(\mathrm{B}_{5}\right)$ & -0.239 & -3.136 \\
Sigma-square & 0.399 & $4.699^{* * *}$ \\
Gamma $(\gamma)$ & 0.322 & $2.054^{* * *}$ \\
Log likelihood function & -116.416 & \\
LR test of the one-sided error & 50.001 & \\
\hline
\end{tabular}

$*, * *$, and $* * *$ significant at $10 \%, 5 \%$, and $1 \%$ levels respectively

Based on Table 5, several variables of technical inefficiency are significant except for employee training expenses, the ratio of highly-qualified employees, the ratio of employees with secondary education, and the dummy firm's size. The negative sign indicates that an increase in the variable will decrease the technical inefficiency while the positive sign indicates otherwise. Wage rates play an important role with real coefficients of -0.779 and significant at $5 \%$ significance level. This shows that when employees' wages increase by 1 unit, the technical inefficiency will decrease at 0.008 points. Based on the statements of National Accounts Annual GDP (2005-2011) for the period of 2005 to 2010, there was an increase of $67.0 \%$ or RM1.2 billion of total salaries and wages paid to employees of transportation manufacturing industries in Malaysia. This shows an increase in wages to employees can motivate employees to improve their productivity and ultimately increase the amount of production output at an optimal level. In fact, the level of technical efficiency of a firm will also increase. These results support the studies by Yao and Zhang (2001), Muhlau and Lindenberg (2003), and Liew, Zulridah, and Tee (2012).

Besides that, ICT cost will also significantly influence output at 5\% significance level. When ICT cost increased by 1 unit, the technical inefficiency will decrease by 0.036 points. These cost include services, hardware consultancy, software consultancy and supply, data processing services, and database activities as well as online communication or facsimile. According to Heshmati and Yang (2006), and $\mathrm{Wu}$ (2008), the contribution of ICT capital investment through productivity can also generate a significant positive result. The increase in these expenses has led to a reduction in engineering firm operating inefficiencies. In fact, Mahadevan and 
Mansor (2007) posited that investment in ICT is extremely important to improve the efficiency and productivity of a firm.

Nonetheless, the ratio of capital-labour indicates an increase in technical inefficiency. The result shows that when the ratio of capital-labour increases by 1 unit, the inefficiency will increase by $0.7 \%$. This result is inconsistent with those from past studies which claimed that the ratio of capital-labour has a positive relationship with the determinants of efficiency and inefficiency, such as in Nelson and Phelps (1966), Maudos, Pastor, and Serrano (1999), Jacobs, Nahuis, and Tang (2000), Stevens and Kneller (2003), and Amdun (2007). However, this study is consistent with the findings by Noor Aini, Basri, and Putri (2008) who found the capital-labour ratio is positively related with engineering firms inefficiency. Results obtained from this study are associated with excess capacity in the use of capital for the industrial manufacturing of transport. When there is an increase in the capital such as the improvement of technology and labour efficiency which is not timely upgraded, then there is the effect of increasing inefficiency engineering firm because employees need to adapt to new technology. According to the DOS, the capital-labour ratio experienced a negative growth of $-4.0 \%$ in 2010 .

Table 5

Determinants of technical inefficiency

\begin{tabular}{|c|c|c|}
\hline \multirow{2}{*}{ Variable and parameter } & Model SF & \multirow{2}{*}{ t-value } \\
\hline & Translog & \\
\hline Constants $\left({ }_{0}\right)$ & 1.183 & $1.683 *$ \\
\hline LnRatio of capital-labour $\left({ }_{1}\right)$ & 0.721 & $3.759 * * *$ \\
\hline LnEmployee training expenses $(2)$ & 0.956 & 0.914 \\
\hline LnRatio of TIER $\left(_{3}\right)$ & -0.199 & -1.377 \\
\hline LnRatio of SEC $\left({ }_{4}\right)$ & 1.186 & 1.373 \\
\hline LnWages (5) & -0.779 & $-3.568 * * *$ \\
\hline LnCommunication expenses ${ }_{6}$ ) & -3.633 & $-3.786^{* * *}$ \\
\hline Dummy firms size ${ }_{7}$ ) & 0.0185 & 0.067 \\
\hline
\end{tabular}

$*, * *$, and $* * *$ significant at $10 \%, 5 \%$, and $1 \%$ levels respectively

\section{CONCLUSION}

This study aims to measure the level of efficiency and analyse the determinants of the technical inefficiency of transport manufacturing industry in Malaysia. The analysis was based on data gathered from the DOS comprises of 130 firms 
involved in the overall six subsectors of transport manufacturing firms in Malaysia. The findings were obtained through hypotheses which indicate that the function of translog production being selected to investigate the efficiency level and determinants of firms' inefficiency. All in all, the level of technical efficiency of the transport manufacturing industry is still moderate, although $66 \%$ of the operating firms were above 0.50 of the efficiency range.

The following findings indicate that firms which belonged in third and fourth subsectors had the most participation in this study. The regression result reveals that determinants such as employees wage rates and the cost of ICT are significant in reducing firms inefficiency. Meanwhile, the ratio of capital-labour is found to have a negative relationship since the result shows its increase causes firm inefficiency. In conclusion, transport manufacturing firms in Malaysia should take initiatives to improve employees wage rates for the purposes of improving employees' productivity and motivation which will eventually increase the amount of production in the future. The increase in wage payment can be given based on employees' performance, experience, and occupational situation. Besides that, work factors such as duties, responsibilities, and work conditions should be taken into account when firms are considering to raise employees' wage rates.

Furthermore, firms need to spend on ICT to improve production that can result in transport manufacturing firms' efficiency. Employees with knowledge in ICT can improve their knowledge and skills besides strengthening the network of production market even at the local level. This is in line with the 11th Malaysia Plan in accelerating the industries growth based on knowledge in the enhancement of productivity through innovations to strengthen competitiveness and generate affluence.

The study, however, has a limitation. It is difficult to have access to firm's data. Most of the employers were reluctant to cooperate in answering the questionnaires submitted by the DOS. This has caused difficulties in obtaining extensive firm's data which is valuable for this study. Based on the limitations that have been encountered in this study's, the following are some recommendations for further research. First, increasing the number of existing firms to obtain the results of a more comprehensive technical competence. Second, additional variables that affect technical inefficiency can be investigated such as research and development, exports and imports. Third, a further research to identify and compare the results of using two different approaches in modelling the SFA and DEA (data envelopment analysis). The comparisons of the results can indicate whether there are differences or similarities in the obtained results. 


\section{REFERENCES}

Aigner, D., Lovell, C.K. \& Schmidt, P. (1977). Formulation and estimation of stochastic frontier production function models. Journal of Econometrics, 6(1), 21-37. https://doi.org/10.1016/0304-4076(77)90052-5

Ajibefun, I.A. (2008). Technical efficiency analysis of micro-enterprises: Theoretical and methodological approach of the stochastic frontier production functions applied to Nigerian data. Journal of African Economies, 17(2), 161-206. https://doi. org/10.1093/jae/ejm009

Almeida, R., \& Carneiro, P. (2009). The return to firm investments in human capital. Labour Economics, 16(1), 97-106. https://doi.org/10.1016/j.labeco.2008.06.002

Alvarez, R., \& Crespi, G. (2003). Determinants of technical efficiency in small firms. Small Business Economics, 20(3), 233-244. https://doi.org/10.1023/A:1022804419183

Amdun P. Z (2007). Kajian mengenai perbezaan produktiviti antara syarikat asing dan syarikat tempatan dalam industri automotif di Malaysia. Master dissertation, Universiti Kebangsaan Malaysia, Malaysia.

Amornkitvikai, Y., Harvie, C., \& Charoenrat, T. (2014). Estimating a technical inefficiency effects model for Thai manufacturing and exporting enterprises (SMEs): A stochastic frontier (SFA) and data envelopment analysis (DEA) approach. In Proceedings of Informing Science \& IT Education Conference (InSITE) 2014, (pp. 363-390).

Andersson, B., Holmlund, B., \& Lindh, T. (2002). Labor productivity, age and education in Swedish mining and manufacturing 1985-96. Unpublished paper, mimeo, Department of Economics, University of Uppsala, Sweden.

Arunsawadiwong, S. (2007). Productivity trends in the Thai manufacturing sector: The preand post-crisis evidence relating to the 1997 economic crisis. $\mathrm{PhD}$ dissertation, School of Economics and Finance, University of St. Andrews, Scotland.

Asid, R. (2010). The technical efficiency analyses of manufacturing sector in Malaysia: Evidence from the First Industrial Master Plan (1986-1995). Asian Social Science, 6(2), 99-107. https://doi.org/10.5539/ass.v6n2p99

Badunenko, O., Fritsch, M., \& Stephan, A. (2008). What drives the productive efficiency of a firm? The importance of industry, location, R\&D, and size. DIW Berlin Discussion Paper No. 775. https://doi.org/10.2139/ssrn.1118303

Barrett, A., \& O'Connell, P. J. (2001). Does training generally work? The returns to incompany training. Industrial \& Labor Relations Review, 54(3), 647-662. https://doi.org/10.1177/001979390105400307 \& https://doi.org/10.2307/2695995

Batra, G., \& Tan, H. (2003). SME technical efficiency and its correlates: Cross-national evidence and policy implications. World Bank Institute Working Paper, Washington, DC.

Battese, G.E., \& Coelli, T.J. (1992). Frontier production functions, technical efficiency and panel data: With application to paddy farmers in India. Journal of Productivity Analysis, 3(1), 149-165. https://doi.org/10.1007/bf00158774

Battese, G.E., \& Coelli, T.J. (1995). A model for technical inefficiency effects in a stochastic frontier production function for panel data. Empirical Economics, 20(2), 325332. https://doi.org/10.1007/BF01205442 
Battese, G.E., \& Corra, G.S. (1977). Estimation of a production frontier model: With application to the pastoral zone of Eastern Australia. Australian Journal of Agricultural Economics, 21(3), 169-179. https://doi.org/10.1111/j.1467-8489. 1977.tb00204.x

Bertrand, J.M.A. (2013). Evolution of structural indicators: China and its regions 19812010. Journal of Chinese Economic and Foreign Trade Studies 6(3), 100-118. https://doi.org/10.1108/JCEFTS-04-2013-0010

Charoenrat, T., Harvie, C., \& Amornkitvikai, Y. (2013). Thai manufacturing small and medium sized enterprise technical efficiency: Evidence from firm-level industrial census data. Journal of Asian Economics, 27, 42-56. https://doi.org/10.1016/j. asieco.2013.04.011

Chavas, J.P., \& Aliber, M. (1993). An analysis of economic efficiency in agriculture: A nonparametric approach. Journal of Agricultural and Resource Economics, 18(1), 1-16. https://doi.org/10.1016/S0169-5150(97)00030-3

Chowdhury, S.K. (2006). Investments in ICT-capital and economic performance of small and medium scale enterprises in East Africa. Journal of International Development, 18(4), 533-552. https://doi.org/10.1002/jid.1250

Chu, S.N., \& Kalirajan, K. (2011). Impact of trade liberalisation on technical efficiency of Vietnamese manufacturing firms. Science, Technology \& Society, 16(3), 265-284. https://doi.org/10.1177/097172181101600302

Coelli, T.J. (1996). A guide to FRONTIER version 4.1: A computer program for stochastic frontier production and cost function estimation. CEPA Working Paper, 96(07), $1-32$.

Coelli, T.J., Rao, D.S.P., \& Battese, G.E. (1998). An introduction to efficiency and productivity analysis. Boston: Kluwer Academic Publisher. https://doi.org/ 10.1007/978-1-4615-5493-6

Coelli, T.J., Rao, D.S.P., O'Donnell, C.J., \& Battese, G. E. (2005). An introduction to efficiency and productivity analysis. New York: Springer Science \& Business Media.

Cullinane, K., Wang, T.F., Song, D.W., \& Ji, P. (2006). The technical efficiency of container ports: Comparing data envelopment analysis and stochastic frontier analysis. Transportation Research Part A: Policy and Practice, 40(4), 354-374. https://doi.org/10.1016/j.tra.2005.07.003

Debreu, G. (1951). The coefficient of resource utilization. Econometrica: Journal of the Econometric Society, 19(3), 273-292. https://doi.org/10.2307/1906814

Essmui, H., Madeline, B., Faridah, S., \& Shamshubarida, R. (2013). Technical efficiency of manufacturing enterprises in Libya: A stochastic frontier analysis. International Journal of Management \& Information Technology, 5(2), 528-535.

Farrell, M.J. (1957). The measurement of productive efficiency. Journal of the Royal Statistical Society. Series A (General), 120(3), 253-290. https://doi.org/ $10.2307 / 2343100$

Giuri, P., Torrisi, S., \& Zinovyeva, N. (2008). ICT, skills, and organizational change: Evidence from Italian manufacturing firms. Industrial and Corporate Change, 17(1), 29-64. https://doi.org/10.1093/icc/dtm038 
Huang, T.L., Hallam, A., Orazem, P.F., \& Paterno, E.M. (1998). Empirical tests of efficiency wage models. Economica, 65(257), 125-143. https://doi.org/10.1111/14680335.00117

Hempell, T. (2005). What's spurious, what's real? Measuring the productivity impacts of ICT at the firm-level. Empirical Economics, 30(2), 427-464. https://doi. org/10.1007/s00181-005-0248-6

Heshmati, A., \& Yang, W.S. (2006). Contribution of ICT to the Chinese economic growth. Retrieved from https://core.ac.uk/download/pdf/7088842.pdf

Idiong, I.C. (2007). Estimation of farm level technical efficiency in smallscale swamp rice production in cross river state of Nigeria: A stochastic frontier approach. World Journal of Agricultural Sciences, 3(5), 653-658.

Idris, N.D.M., Siwar, C., \& Talib, B. (2013). Determinants of technical efficiency on pineapple farming. American Journal of Applied Sciences, 10(4), 426-432. https://doi.org/10.3844/ajassp.2013.426.432

Inglada, V., Coto-Millan, P., \& Rodriguez-Alvarez, A. (1999). Economic and technical efficiency in the world air industry. International Journal of Transport Economics / Rivista Internazionale di Economia dei Trasporti, 26(2), 219-236.

Ismail, R., \& Tendot Abu Bakar, N. (2008). Analisis kecekapan teknikal firma Melayu dalam sektor pembuatan Malaysia. International Journal of Management Studies, 15(2), 143-163.

Ismail, R., \& Jajri, I. (2008). Analisis perubahan kecekapan teknikal, perubahan teknologi, pertumbuhan produktiviti faktor keseluruhan dan pertumbuhan output dalam industri peralatan pengangkutan di Malaysia. Sains Humanika, 49(1), 31-48. https://doi.org/10.11113/jt.v49.208

Jacobs, B., Nahuis, R., \& Tang, P. J. (2000). Human capital, R\&D, productivity growth and assimilation of technologies in the Netherlands. In B. van Ark, S.K. Kuipers, \& G.H. Kuper (Eds.), Productivity, technology and economic growth (pp. 293-315). New York: Springer. https://doi.org/10.1007/978-1-4757-3161-3_10

Jaafar, A.H., Mustapha, N.H.N., \& Talib, B.A. (2004). Analisis kemajuan pembangunan dan tahap kecekapan penternakan akuakultur di Malaysia: Kajian kes. Paper presented at Seminar Kebangsaan Fakulti Ekonomi dan Perniagaan, Port Dickson, Negeri Sembilan.

Karunaratne, N.D. (2012). Macroeconomic reform and technical efficiency in Australian manufacturing: A stochastic production frontier analysis. Economia Internazionale / International Economics, 66(3), 345-369.

Khalifah, N.A. (2013). Ownership and technical efficiency in Malaysia's automotive industry: A stochastic frontier production function analysis. The Journal of International Trade \& Economic Development, 22(4), 509-535. https://doi.org/1 $0.1080 / 09638199.2011 .571702$

Kumbhakar, S., \& Lovell, C.A.K. (2003). Stochastic frontier analysis. Cambridge: Cambridge University Press.

Lieberman, M.B., \& Dhawan, R. (2005). Assessing the resource base of Japanese and US auto producers: A stochastic frontier production function approach. Management Science, 51(7), 1060-1075. https://doi.org/10.1287/mnsc.1050.0416 
Liew, C.S., Zulridah, M.N., \& Tee, B.A. (2012). Kesan ICT terhadap produktiviti pekerja dalam sektor perkhidmatan terpilih di Malaysia. Jurnal Ekonomi Malaysia, 46(2), $115-126$.

Mahadevan, R., \& Mansor. I. (2007). Competitiveness and workforce status in the Malaysian micro-electronics sector. Kuala Lumpur: Economics, East Asian Development Network (EADN).

Maudos, J., Pastor, J.M. \& Serrano, L. (1999). Total factor productivity measurement and human capital in OECD countries. Economics Letters, 63(1), 39-44. https://doi. org/10.1016/S0165-1765(98)00252-3

Mazumder, R., \& Adhikary, M. (2010). Measuring technical efficiency in the Indian automobile industry. South Asia Economic Journal, 11(1), 53-67. https://doi. org/10.1177/139156141001100104

Md Isa, R. (2005). Total factor productivity growth, efficiency and technological progress of the Malaysian manufacturing sector. PhD dissertation, Universiti Putra Malaysia, Malaysia.

Meeusen, W. \& van den Broeck, J. (1977). Efficiency estimation from Cobb-Douglas production functions with composed error. International Economic Review, 18(2), 435-444. https://doi.org/10.2307/2525757

Meng, Q., \& Li, M. (2002). New economy and ICT development in China. Information Economics and Policy, 14(2), 275-295. https://doi.org/10.1016/S01676245(01)00070-1

Minh, N.K., Long, G.T., \& Thang, B.N. (2007). Technical efficiency of small and medium manufacturing firms in Vietnam: Parametric and non-parametric approaches. Korean Economic Review, 23(1), 187-221.

Mini, F., \& Rodriguez, E. (2000). Technical efficiency indicators in a Philippine manufacturing sector. International Review of Applied Economics, 14(4), 461473. https://doi.org/10.1080/02692170050150138

MITI (Ministry of International Trade and Industry). (2013). National automotive policy 2014. Kuala Lumpur: Ministry of International Trade and Industry.

MITI (Ministry of International Trade and Industry). (2014). MITI report. Kuala Lumpur: Ministry of International Trade and Industry.

Muhlau, P., \& Lindenberg, S. (2003). Efficiency wages: Signals or incentives an empirical study of the relationship between wage and commitment. Journal of Management and Governance, 7(4), 385-400. https://doi.org/10.1023/A:1026261223790

Murthy, D.S., Sudha, M., Hegde, M.R., \& Dakshinamoorthy, V. (2009). Technical efficiency and its determinants in tomato production in Karnataka, India: Data envelopment analysis (DEA) approach. Agricultural Economics Research Review, 22(2), 215224.

Mustapha, N.H.N., \& Talib, B.M. (2004). Technical efficiency and total factor growth in selected Malaysian manufacturing industries. In D. Padmini, B.T. Poo, \& Mohd Nasir Mohd Saukani (Eds.), Proceeding Seminar Economic and Social Competitiveness Towards Strengthening Economic Development, 11-13 June 2004, Port Dickson, Malaysia. 
Mustapha, N.H.N. (2011). Technical efficiency for rubber smallholders under RISDA's supervisory system using stochastic frontier analysis. Journal of Sustainability Science and Management, 6(1), 156-168.

Nelson, R.R., \& Phelps, E.S. (1966). Investment in humans, technological diffusion, and economic growth. The American Economic Review, 56(1/2), 69-75.

Noor, Z.M., \& Ismail, R. (2007). Analisis kecekapan teknik dalam industri skel kecil dan sederhana di Malaysia. International Journal of Management Studies, 14(1), 199-217.

Noor Aini, A.K., Basri, A.T., \& Putri Z. A. (2008). Are foreign multinationals more efficient? A stochastic production frontier analysis of Malaysia's automobile industry. International Journal of Management Studies, 15, 91-113.

Oum, T.H., \& Yu, C. (2012). Winning airlines: Productivity and cost competitiveness of the world's major airlines. New York: Springer Science \& Business Media.

Perbadanan Produktiviti Malaysia. (2009/2010). Laporan produktiviti 2005 dan 2009. Kuala Lumpur: Perbadanan Produktiviti Malaysia.

Perbadanan Produktiviti Malaysia. (2013/2014). Laporan produktiviti 2013 dan 2014. Kuala Lumpur: Perbadanan Produktiviti Malaysia.

Petrakis, P.E., \& Stamatakis, D. (2002). Growth and educational levels: A comparative analysis. Economics of Education Review, 21(5), 513-521. https://doi. org/10.1016/S0272-7757(01)00050-4

Petrin, A., White, T.K., \& Reiter, J.P. (2011). The impact of plant-level resource reallocations and technical progress on US macroeconomic growth. Review of Economic Dynamics, 14(1), 3-26. https://doi.org/10.1016/j.red.2010.09.004

Pitt, M.M., \& Lee, L.F. (1981). The measurement and sources of technical inefficiency in the Indonesian weaving industry. Journal of Development Economics, 9(1), 43-64. https://doi.org/10.1016/0304-3878(81)90004-3

Porcelli, F. (2009). Measurement of technical efficiency. A brief survey on parametric and non-parametric techniques (vol. 11, pp. 1-27). United Kingdon: University of Warwick.

Radam, A., Abu, M., \& Abdullah, A.M. (2008). Technical efficiency of small and medium enterprise in Malaysia: A stochastic frontier production model. International Journal of Economics and Management, 2(2), 395-408.

Rosli, M., \& Kari, F. (2008). Malaysia's national automotive policy and the performance of proton's foreign and local vendors. Asia Pacific Business Review, 14(1), 103-118. https://doi.org/10.1080/13602380701661044

Sanchez, P.C., \& Villaroya, J.M. (2000). Efficiency, technical change and productivity in the European rail sector: A stochastic frontier approach. International Journal of Transport Economics / Rivista Internazionale di Economia dei Trasporti, 27(1), 55-76.

Sinani, E., Jones, D.C., \& Mygind, N. (2008). Determinants of firm-level technical efficiency: Evidence using stochastic frontier approach. Corporate Ownership \& Control, 5(3), 225-239. https://doi.org/10.22495/cocv5i3c1p7

Stevens, P.A., \& Kneller, R. (2003). Absorptive capacity and frontier technology: Evidence from OECD manufacturing industries. Oxford Bulletin of Economics and Statistics, 68(8), 1-21. 
Tingley, D., Pascoe, S., \& Coglan, L. (2005). Factors affecting technical efficiency in fisheries: Stochastic production frontier versus data envelopment analysis approaches. Fisheries Research, 73(3), 363-376. https://doi.org/10.1016/j. fishres.2005.01.008

Tran, T.B., Grafton, R.Q., \& Kompas, T. (2008). Firm efficiency in a transitional economy: Evidence from Vietnam. Asian Economic Journal, 22(1), 47-66. https://doi. org/10.1111/j.1467-8381.2008.00268.x

Vitaliano, D.F. (2002). An econometric assessment of the economic efficiency of State Departments of Transportation. International Journal of Transport Economics / Rivista Internazionale di Economia dei Trasporti, 29(2), 167-180.

Wadud, I.M. (2008). Productivity growth and efficiency change in Malaysian manufacturing: Recent evidence from disaggregated data. Empirical Economics Letters, 7(5), 497-504.

Wu, Y.R. (2008). Productivity, efficiency and economic growth in China. UK: Palgrave Macmillan Press. https://doi.org/10.1057/9780230228252

Yao, Y., \& Zhang, Q. (2001). Analysis of technical efficiency in Chinese industry. Working Paper No. 200103, National Center for Economic Research, Tsinghua University, China.

Zhang, Y., Tang, Y., \& Findlay, C. (2010). Productivity effects of services trade liberalization: Evidence from Chinese firm-level data. In International Conference on China and the Global Economy: Economic Integration and Protection, June 2010, Beijing. 
